\title{
Case Report: A rare cause of oral bullae: Angina bullosa
}

\section{hemorrhagica [version 1; peer review: 2 approved]}

\author{
Salih Levent Cinar (iD), Demet Kartal' ${ }^{1}$ Özlem Canöz², Murat Borlu1, \\ Ayten Ferahbas ${ }^{1}$
}

${ }^{1}$ Dermatology and Venereology, Erciyes University Faculty of Medicine, Kayseri, Turkey

2Pathology, Erciyes University Faculty of Medicine, Kayseri, Turkey

\section{V1 First published: 08 Nov 2017, 6:1974 \\ https://doi.org/10.12688/f1000research.12977.1}

Latest published: 08 Nov 2017, 6:1974

https://doi.org/10.12688/f1000research.12977.1

\section{Abstract}

Angina bullosa hemorrhagica $(\mathrm{ABH})$ is a benign disorder of the oral cavity. Clinically, oral, blood-filled blisters are seen. To give a proper diagnosis, one should rule out any other cause. We aim to present this case in order to emphasize this rare cause of oral bullae which is necessary to be differentiated from many serious dermatological and hematological disorders.

Keywords

Angina bullosa hemorrhagica, blister, oral mucosa

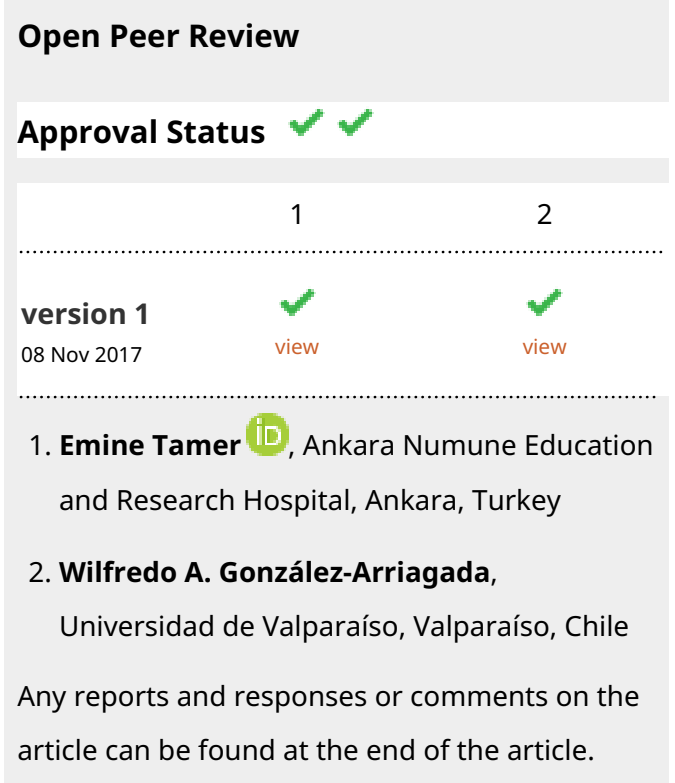

Corresponding author: Salih Levent Cinar (sleventcinar@yahoo.com)

Author roles: Cinar SL: Conceptualization, Data Curation, Formal Analysis, Investigation, Methodology, Software, Validation, Writing Original Draft Preparation; Kartal D: Data Curation, Formal Analysis, Investigation, Methodology, Supervision; Canöz Ö: Data Curation, Investigation, Methodology, Visualization, Writing - Original Draft Preparation; Borlu M: Conceptualization, Formal Analysis, Methodology, Software, Supervision, Writing - Review \& Editing; Ferahbas A: Conceptualization, Methodology, Supervision, Validation, Writing - Review \& Editing

Competing interests: No competing interests were disclosed.

Grant information: The author(s) declared that no grants were involved in supporting this work.

Copyright: $\odot 2017$ Cinar SL et al. This is an open access article distributed under the terms of the Creative Commons Attribution License, which permits unrestricted use, distribution, and reproduction in any medium, provided the original work is properly cited.

How to cite this article: Cinar SL, Kartal D, Canöz Ö et al. Case Report: A rare cause of oral bullae: Angina bullosa hemorrhagica [version 1; peer review: 2 approved] F1000Research 2017, 6:1974 https://doi.org/10.12688/f1000research.12977.1

First published: 08 Nov 2017, 6:1974 https://doi.org/10.12688/f1000research.12977.1 


\section{Introduction}

Most oral bullae are caused by vesiculo-bullous disorders, blood dyscrasia and systemic diseases. One rare cause of oral bullae is angina bullosa hemorrhagica $(\mathrm{ABH})$, a term which was first coined by Badham in $1967^{1}$. Later, other synonyms like localized oral purpura and stomatopompholyx hemorrhagica were also used ${ }^{2}$.

In this case report our goal is to present a rare cause of oral blood-filled bullae, and to describe its differential diagnosis and treatment.

\section{Case report}

A 43 year-old male patient was admitted to our dermatology and venereology outpatient clinic with a complaint of a dark red, oral blister. He stated that his complaints started three years ago and since then he had experienced such episodes a few times each year. He had visited a few physicians but had not been able to get a proper diagnosis and because the blisters healed spontaneously he did not seek medical advice about his condition. He suspected that hot drinks and crispy food were the cause.

On dermatological examination we observed a tense, bloodfilled bullae on his tongue with no additional dermatologic finding (Figure 1). He did not have any complaints of pain. On examination of the skin, there was nothing but a few seborrheic keratoses.

His biochemical markers and blood count, including platelet levels, were completely normal. Extra tests to rule out blood dyscrasia were performed and the results were normal.

He had no history of drug intake for the last few months, we therefore ruled out fixed drug eruption. Also he had not had any dental procedure or known oral trauma. One other possible diagnosis was a vesiculo-bullous disorder like pemphigus, pemphigoid, bullous lichen and acquired epidermolysis bullosa but he did not have any additional lesions elsewhere. A biopsy specimen was taken for histopathological examination. A subepithelial blister was observed. There were a few inflammatory cells and the subepithelial space was filled with erythrocytes (Figure 2). After the biopsy, a dark red erosion developed, which later healed without scarring.

After ruling out any possible disorder that can cause oral bullae, our diagnosis was angina bullosa hemorrhagica. Shortly after using an anti-bacterial mouthwash the complaints of the patient disappeared.

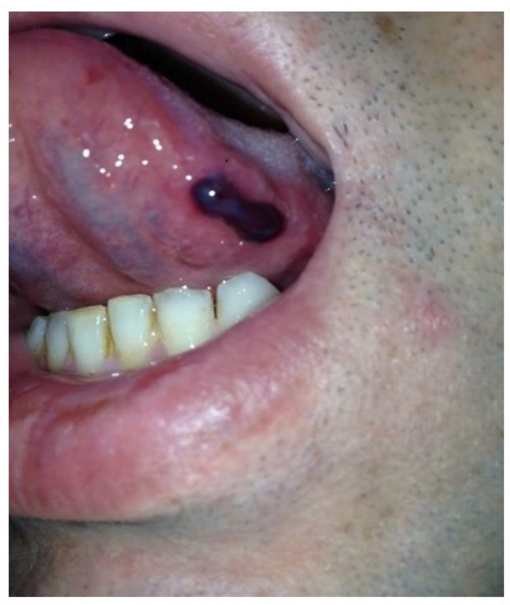

Figure 1. A tense, blood-filled bullae on the tongue.

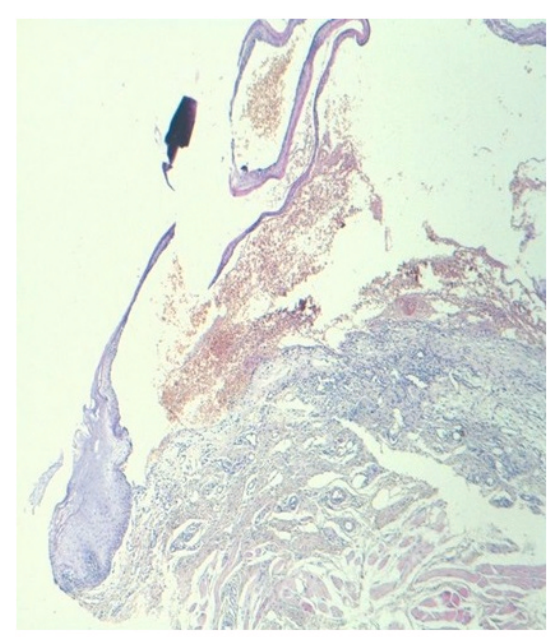

Figure 2. Subepithelial blister and a few inflammatory cells seen in routine hematoxylin and eosin section (10x). The subepithelial space was filled with erythrocytes.

\section{Discussion}

Angina bullosa hemorrhagica ( $\mathrm{ABH})$ is a benign oral cavity disorder with no known origin. The $\mathrm{ABH}$ term was first used in 1967 by Badham. However years ago, in 1933, this condition was described as traumatic oral hemophlyctenosis ${ }^{2}$. It usually affects the middle aged and elderly, with no sex discrimination. It is 
generally asymptomatic but sometimes pain or a sensation of choking can be reported. The term angina comes from this choking sensation. It can be solitary or multiple. Patients usually mention bullae forming during or shortly after a meal. Some patients report burning just before the blister onset, but pain and burning disappear after the bursting of the bullae ${ }^{3}$.

Although $\mathrm{ABH}$ is accepted as a benign disorder, some authors reported a choking or gagging sensation when the lesions are in the posterior pharynx or in the epiglottis ${ }^{3}$. As a rare complication, acute upper airway obstruction was also reported ${ }^{4}$.

The cause of $\mathrm{ABH}$ is still unclear. No underlying hematological or immunological abnormalities have been identified. Trauma and personal predisposition seem to be necessary for the development of the disease. Increased fragility of the oral epithelial connective tissue can make the non-keratinized oral mucosa vulnerable to trauma. Thus, even a minor trauma can lead to breakage of the epithelial-connective tissue junction resulting hemorrhage from the superficial capillaries. The result is subepithelial hemorrhagic bullae $e^{5}$.

High, in 1987, described the relationship between the chronic inhalation of steroids and $\mathrm{ABH}$. In his study none of the 64 patients who used a steroid-free inhaler had a history of oral blistering whereas 15 patients out of 42 who used a steroid-based inhaler had oral blisters. The chronic use of steroid-based inhalers can affect collagen production causing epithelial and mucosal atrophy ${ }^{6}$. The proposal of Ferguson et al. that $\mathrm{ABH}$ could represent a localized amyloidosis failed after Congo red staining 7 .

When the question is the histopathology of $\mathrm{ABH}$, we see subepithelial separation from the lamina propria, with very few inflammatory cells. Parakeratosis in the surrounding tissue can also be seen. When the bullae bursts, the ulcerated epithelium with a chronic inflammatory infiltrate, mainly of lymphocytes, can be detected. Direct immunofluorescence staining for $\operatorname{IgA}$, IgG, IgM and fibrin is negative ${ }^{8}$.

In our case the first few differential diagnoses which came to mind were erythema multiforme, bullous lichen planus, pemphigus, pemphigoid and fixed drug eruption along with blood dyscrasias. After some routine and specific blood tests we were able to rule out blood dyscrasias. As the blister was subepithelial and there were no additional mucosal and cutaneous lesions we eliminated pemphigus probability too.

Unfortunately we were not able to perform direct immunofluorescence staining. However, with the help of the histopathology, we ruled out erythema multiforme as our patient had no recent history of herpes infection or drug intake. Again, with no recent drug intake history and absence of eosinophiles we ruled out fixed drug eruption. Pemphigoid and bullous lichen planus were not considered because our patient had a solitary lesion and this healed spontaneously in a week without any treatment.

As a result, in case of a blood filled bullae, the management should start with a detailed medical history and careful observation of the patient. Later on blood tests and biopsy, both histological and immunofluorescence, should be performed to differentiate it from other diseases. After the proper diagnosis has been made the patient must be informed about the disease. The benign nature of the disease must be emphasized to any individual with this diagnosis. However, any patient with $\mathrm{ABH}$, must also be warned about some rare complications like acute airway obstruction in case of huge palatal or pharyngeal bullae as mentioned by Pahl et $a l^{4}$. Anti-inflammatory or anti-bacterial rinses/sprays can be used to prevent pain and secondary infection.

As dermatologists, we should be aware of one probable diagnosis, $\mathrm{ABH}$, in case of oral blood-filled blisters. We should also keep in mind that many patients do not visit a physician due to the benign and self-limiting nature of the disease.

\section{Consent}

Written informed consent was obtained from the patient for publication of his clinical details and images.

\section{Competing interests}

No competing interests were disclosed.

\section{Grant information}

The author(s) declared that no grants were involved in supporting this work.
1. Badham NJ: Blood blisters and the oesophageal cast. J Laryngol Otol. 1967; 81(7): 791-803.

PubMed Abstract | Publisher Full Text

2. Deblauwe BM, van der Waal I: Blood blisters of the oral mucosa (angina bullosa haemorrhagica). J Am Acad Dermatol. 1994; 31(2 Pt 2): 341-344.

PubMed Abstract | Publisher Full Text

3. Gibson J: Oropharyngeal blood blisters are known as angina bullosa haemorrhagica. BMJ. 1997; 314(7094): 1625.

PubMed Abstract | Publisher Full Text | Free Full Text

4. Pahl C, Yarrow S, Steventon N, et al: Angina bullosa haemorrhagica presenting as acute upper airway obstruction. Br J Anaesth. 2004; 92(2): 283-286. PubMed Abstract | Publisher Full Text
5. Hopkins R, Walker DM: Oral blood blisters: angina bullosa haemorrhagica. $\mathrm{Br} J$ Oral Maxillofac Surg. 1985; 23(1): 9-16. PubMed Abstract | Publisher Full Text

6. High AS, Main DM: Angina bullosa haemorrhagica: a complication of long-term steroid inhaler use. Br Dent J. 1988; 165(5): 176-179. PubMed Abstract

7. Ferguson A, Johnston M, Leach IH, et al.: Angina bullosa haemorrhagica--a localized amyloidosis? J Eur Acad Dermatology Venereol. 2005; 19(4): 513-514. PubMed Abstract | Publisher Full Text

8. Hosain SI, Bounds G, Stanford J: Angina haemorrhagica bullosa causing respiratory obstruction postoperatively. Anaesthesia. 1991; 46(5): 422. PubMed Abstract | Publisher Full Text 


\section{Open Peer Review}

\section{Current Peer Review Status:}

\section{Version 1}

Reviewer Report 11 December 2017

https://doi.org/10.5256/f1000research.14072.r28829

(C) 2017 González-Arriagada W. This is an open access peer review report distributed under the terms of the Creative Commons Attribution License, which permits unrestricted use, distribution, and reproduction in any medium, provided the original work is properly cited.

\section{Wilfredo A. González-Arriagada}

Oral Pathology and Diagnosis, Facultad de Odontología, Universidad de Valparaíso, Valparaíso, Chile

This is an interesting case report of an angina bullosa hemorrhagica of the tongue. This is a rare condition of oral bullae, that is most frequent in hard palate and buccal mucosa. Authors said that the cause is unclear, however most of this bullae are of traumatic origin. For this reason it is important to mention to avoid any traumatic agent, like a malpositioned tooth or a restoration with defects, and the derivation to the dentist. Authors discard other common cause of these bullae that is the thrombocytopenic purpura.

This is a good article about angina bullosa hemorrhagica and it is well-written, but I think that they have to mention how important is to consult with a dentist, and to consider thrombocytopenic purpura as differential diagnosis, including the number of platelet count in the article (authors only said that is normal).

Is the background of the case's history and progression described in sufficient detail? Yes

Are enough details provided of any physical examination and diagnostic tests, treatment given and outcomes?

Yes

Is sufficient discussion included of the importance of the findings and their relevance to future understanding of disease processes, diagnosis or treatment?

Yes

Is the case presented with sufficient detail to be useful for other practitioners? Yes 
Competing Interests: No competing interests were disclosed.

Reviewer Expertise: Oral Pathology and Medicine

I confirm that I have read this submission and believe that I have an appropriate level of expertise to confirm that it is of an acceptable scientific standard.

Reviewer Report 14 November 2017

https://doi.org/10.5256/f1000research.14072.r27743

(C) 2017 Tamer E. This is an open access peer review report distributed under the terms of the Creative Commons Attribution License, which permits unrestricted use, distribution, and reproduction in any medium, provided the original work is properly cited.

\section{Emine Tamer}

Dermatology Clinic, Ankara Numune Education and Research Hospital, Ankara, Turkey

As dermatologists, we encounter oral mucosa pathologies very often. It is very important that we make differential diagnosis. This diagnosis must be kept in mind in oral mucosal pathologies. So that this self-limiting condition is not skipped. This article will raise our awareness on this subject. At the same time this article about angina bullosa hemorrhagica adequate and well-written.

Is the background of the case's history and progression described in sufficient detail? Yes

Are enough details provided of any physical examination and diagnostic tests, treatment given and outcomes?

Yes

Is sufficient discussion included of the importance of the findings and their relevance to future understanding of disease processes, diagnosis or treatment?

Yes

Is the case presented with sufficient detail to be useful for other practitioners?

Yes

Competing Interests: No competing interests were disclosed.

I confirm that I have read this submission and believe that I have an appropriate level of expertise to confirm that it is of an acceptable scientific standard. 
The benefits of publishing with F1000Research:

- Your article is published within days, with no editorial bias

- You can publish traditional articles, null/negative results, case reports, data notes and more

- The peer review process is transparent and collaborative

- Your article is indexed in PubMed after passing peer review

- Dedicated customer support at every stage

For pre-submission enquiries, contact research@f1000.com 